\title{
PENGARUH MODEL PEMBELAJARAN INQUIRY TRAINING DAN MOTIVASI TERHADAP HASIL BELAJAR FISIKA SISWA
}

\author{
Dahlia Megawati Pardede ${ }^{1}$ dan Sondang R. Manurung ${ }^{2}$ \\ ${ }^{1}$ Alumni Mahasiswa Program Studi Pendidikan Fisika Program \\ Pascasarjana UNIMED \\ ${ }^{2}$ Program Studi Pendidikan Fisika Program Pascasarjana UNIMED \\ email: dahliafisika@yahoo.co.id
}

\begin{abstract}
Abstrak. Penelitian ini bertujuan: (a) untuk mengetahui perbedaan hasil belajar fisika siswa yang diajarkan dengan model pembelajaran menggunakan inquiry training dengan pembelajaran konvensional, (b) untuk mengetahui hasil belajar siswa yang diajarkan dengan model pembelajaran inquiry training dan konvensional (c) perbedaan hasil belajar siswa yang memiliki motivasi yang tinggi dan motivasi yang rendah, (d) interaksi antara model pembelajaran dengan motivasi dalam mempengaruhi hasil belajar siswa. Sampel dalam penelitian ini dilakukan secara cluster random sampling sebanyak dua kelas, dimana kelas pertama sebagai kelas eksperimen diterapkan model pembelajaran inquiry training dan kelas kedua sebagai kelas kontrol diterapkan pembelajaran konvensional. Hasil penelitian dapat disimpulkan bahwa: (a) terdapat perbedaan hasil belajar fisika siswa yang diajarkan dengan model pembelajaran inquiry training dan pembelajaran konvensional. (b) hasil belajar siswa yang diajarkan dengan model pembelajaran inquiry training lebih baik dari hasil belajar siswa yang diajarkan dengan pembelajaran konvensional. (c) hasil belajar siswa yang memiliki motivasi tinggi lebih baik dari hasil belajar siswa yang memiliki motivasi rendah. (d) terdapat interaksi antara model pembelajaran dan motivasi terhadap hasil belajar siswa. Hasil belajar siswa yang diajarkan dengan model inquiry training dipengaruhi juga oleh motivasi, hasil belajar siswa yang diajarkan dengan pembelajaran konvensional dipengaruhi oleh motivasi siswa.
\end{abstract}

Katakunci: Motivasi, Inquiry Training, Hasil Belajar

\section{EFFECT OF INQUIRY LEARNING MODEL AND MOTIVATION ON PHYSICS OUTCOMES LEARNING STUDENTS}

\author{
Dahlia Megawati Pardede ${ }^{1}$ and Sondang R. Manurung ${ }^{2}$ \\ ${ }^{1}$ Student Alumni of Physics Education Study Programs Postgraduate \\ School UNIMED \\ ${ }^{2}$ Physics Education Study Programs Postgraduate School UNIMED \\ email: dahliafisika@yahoo.co.id
}

\begin{abstract}
The purposes of the research are: (a) to determine differences in learning outcomes of students with Inquiry Training models and Konvensional models, (b) to determine differences in physics learning outcomes of students who have high motivation and low motivation, (c) to determine the interaction between learning models with the level of motivation in improving student
\end{abstract}


D.M. Pardede dan S.R. Manurung: Pengaruh Model Pembelajaran Inquiry Training dan Motivasi terhadap Hasil Belajar Fisika Siswa
Jurnal Pendidikan Fisika p-ISSN 2252-732X e-ISSN 2301-7651

Physics learning outcomes. The results were found: (a) there are differences in physical students learning outcomes are taught by Inquiry Training models and konvensional models. (b) learning outcomes of students who are taught by Inquiry Learning Model Training better than student learning outcomes are taught with konvensional model. (c) there is a difference in student's learning outcomes that have high motivation and low motivation. (d) Student learning outcomes that have a high motivation better than student learning outcomes than have a low motivation. (e) there is interaction between learning and motivation to student learning outcomes. Learning outcomes of students who are taught by the model is influenced also by the motivation, while learning outcomes of students who are taught with konvensional models are not affected by motivation.

\section{Keywords: Motivation, Inquiry Training, Learning Outcomes}

\section{PENDAHULUAN}

Pendidikan merupakan salah satu usaha untuk mencerdaskan kehidupan bangsa dan merupakan suatu kunci pokok untuk mencapai cita-cita suatu bangsa. Pendidikan memegang peranan yang sangat penting bagi pengembangan siswa agar kelak menjadi sumber daya manusia berkualitas. Keberhasilan dalam bidang pendidikan membuat kualitas suatu bangsa mendapat pengakuan di seluruh dunia. Namun, pada kenyataannya kualitas pendidikan di Indonesia masih sangat memprihatinkan. Driana, (2013) menyatakan hasil Trends in International Mathematics and Science Studies (TIMSS) 2011, yang baru dipublikasikan, semakin menegaskan kondisi pendidikan di tanah air sangat memprihatinkan hasil sains tak kalah mengecewakan. Indonesia di urutan ke 40 dari 42 negara dengan nilai rata-rata 406 di bawah Indonesia ada Maroko dan Ghana. Yang paling mengherankan nilai matematika dan sains siswa kelas VIII Indonesia bahkan berada di bawah Palestina yang negaranya didera konflik berkepanjangan.

Rendahnya kemampuan siswa-siswi Indonesia di matematika, sains, dan membaca juga tercermin dalam. Hasil Programme for International Student Assessment (PISA) 2012, Indonesia berada di peringkat ke 64 dari 65 negara yang berpartisipasi dalam tes. Indonesia telah ikut serta dalam siklus tiga tahunan penilaian tersebut yaitu 2003, 2006, dan 2009 hasilnya sangat memprihatinkan. Siswa-siswi Indonesia secara konsisten terpuruk di peringkat bawah.

Berbagai upaya dilakukan pemerintah untuk meningkatkan mutu pendidikan antara lain dengan melengkapi sarana dan prasarana, meningkatkan kualitas pendidik, serta penyempurnaan kurikulum yang menekankan pada aspek-aspek yang bermuara pada peningkatkan dan pengembangan kecakapan hidup yang diwujudkan melalui pencapaian kompetisi peserta didik untuk dapat menyesuaikan diri dan berhasil dimasa yang akan datang.

Pengkajian tentang faktor-faktor yang mempengaruhi mutu hasil belajar merupakan usaha awal yang seharusnya dilakukan dalam rangka perbaikan dan peningkatan mutu hasil belajar. Kualitas lulusan sekolah juga harus diperhatikan, karena banyak sekali faktor yang mempengaruhinya, ditinjau dari unsur siswa masih banyak faktor yang mempengaruhi baik faktor yang ada dalam diri siswa maupun dari luar diri siswa. Faktor yang ada dalam diri anak didik adalah faktor fisiologis dan psikologis. Misalnya: persepsi, minat, sikap, motivasi, bakat, $I Q$. Sedangkan faktor yang berada di luar diri anak didik misalnya lingkungan tempat tinggal, keadaan sosial ekonomi orang tua.

Fisika merupakan ilmu sains yang diajarkan di sekolah dan salah satu pelajaran yang dinilai dalam PISA. Berdasarkan hasil wawancara dengan salah satu guru di SMA Kalam Kudus Medan menyatakan pelajaran fisika sering kali dianggap siswa merupakan pelajaran yang sulit dan sangat membosankan, tidak mengherankan nilai pelajaran fisika lebih rendah dibandingkan pelajaran lain. Terlihat dari nilai rata-rata hasil ulangan harian fisika siswa di SMA Kalam Kudus Medan masih banyak di bawah Kriteria ketuntasan Minimal (KKM). Konsep fisika yang bersifat abstrak yang harus diserap siswa dalam waktu yang relatif terbatas menjadikan ilmu fisika menjadi salah satu mata pelajaran yang paling sulit bagi siswa sehingga banyak siswa yang gagal dalam belajar. Pada umumnya siswa cenderung dengan menghapal rumus dari pada secara aktif membangun pemahaman mereka sendiri terhadap konsep fisika. Proses pembelajaran yang masih tecaher centered tidak memberikan keleluasaan kepada siswa untuk berkembang secara mandiri, dimana guru hanya menekankan pada pemahaman konsep melalui hafalan-hafalan.

Motivasi merupakan salah satu faktor yang diduga besar pengaruhnya terhadap hasil belajar. Motivasi didefenisikan sebagai proses yang menstimulasi perilaku atau menggerakkan manusia untuk bertindak (Arends, 2007). Motivasi belajar adalah segala sesuatu yang dapat memotivasi peserta didik atau individu untuk belajar (Sani, 2013). Tella (2007) menyatakan siswa yang memiliki motivasi tinggi dan rendah memiliki prestasi belajar yang berbeda pula. 
D.M. Pardede dan S.R. Manurung: Pengaruh Model Pembelajaran Inquiry Training dan Motivasi terhadap Hasil Belajar Fisika Siswa

Guru harus mampu memperbaiki hasil belajar fisika siswa yang rendah dengan memilih model pembelajaran yang sesuai, dan untuk mengatasi hal tersebut salah satu cara yang digunakan untuk meningkatkan prestasi belajar siswa adalah menggunakan model pembelajaran yang tepat sasaran ketika menyampaikan materi pembelajaran. Belajar harus sesuatu yang menyenangkan, simpel, menyenangkan dan efektif bagi diri siswa. Dengan begitu hasil belajar siswa akan meningkat, dan akan semakin memberikan kontribusi yang besar baik kegiatan proses belajar mengajar.

Salah satu model pembelajaran yang tepat dan sesuai dalam penelitian ini adalah dengan menggunakan model inquiry training. Joyce, dkk, (2009) menyatakan model pembelajaran inquiry training dirancang untuk membawa siswa secara langsung ke dalam proses ilmiah melalui latihan-latihan yang dapat memadatkan proses ilmiah tersebut ke dalam periode waktu yang singkat, tujuannya adalah membantu siswa mengembangkan disiplin dan mengembangkan keterampilan intelektual yang diperlukan untuk mengajukan pertanyaan dan menemukan jawabannya berdasarkan rasa ingin tahu.

Melalui model pembelajaran inquiry training siswa diharapkan aktif mengajukan pertanyaan mengapa sesuatu terjadi kemudian mencari dan mengumpulkan serta memproses data secara logis untuk selanjutnya mengembangkan strategi intelektual yang dapat digunakan untuk dapat menemukan jawaban atas pertanyaan tersebut. Siddiqui (2013) menyatakan Model pelatihan inquiry training memberikan lebih menekankan pada pengembangan kesadaran dan menguasai proses penyelidikan.

Latihan inkuiri memberi kesempatan kepada peserta didik untuk mengembangkan keingintahuannya dan melakukan eksplorasi menyelidiki sebuah fenomena (Sani, 2013). Model Pembelajaran inquiry training terdapat tiga prinsip kunci, yaitu pengetahuan bersifat tentatif, manusia memiliki sifat ingin tahu yang alamiah, dan manusia mengembangkan individual secara mandiri. Prinsip pertama menghendaki proses penelitian secara berkelanjutan, prinsip kedua mengindikasikan pentingkan siswa melakukan eksplorasi, dan yang ketiga kemandirian, akan bermuara pada pengenalan jati diri dan sikap ilmiah, tujuan umum dari model latihan inkuiri adalah membantu peserta didik mengembangkan keterampilan intelektual dan keterampilan lainnya, seperti mengajukan pertanyaan dan menemukan (mencari) jawaban yang berawal dari keingintahuan mereka.

Model pembelajaran inquiry training memiliki lima fase sebagai sintaks pembelajarannya. 1) menghadapkan pada masalah dan merumuskannya. 2)merumuskan hipotesis. 3) mengumpulkan data eksperimen. 4) mengolah dan memformulasikan suatu data. 5) analisis proses dan hasil penyelidikan. Model pembelajaran inquiry training memiliki kelebihan a). Dapat membangkitkan potensi intelektual siswa, b). Peserta didik yang semula memperoleh extrinsic reward dalam keberhasilan belajar (seperti mendapat nilai baik

Vol.5 No.1 Juni 2016
Jurnal Pendidikan Fisika

p-ISSN 2252-732X

e-ISSN 2301-7651 dari pengajar), dalam pendekatan inkuiri ini dapat memperoleh intrinsic reward, c). Peserta didik dapat mempelajari heuristik (mengolah pesan atau informasi) dari penemuan (discovery).

\section{METODE PENELITIAN}

Penelitian ini dilaksanakan di SMA Swasta Kalam Kudus Medan. Populasi dalam penelitian ini adalah seluruh siswa kelas X SMA Swasta Kalam Kudus Medan Tahun Pembelajaran 2014/2015. Jumlah populasi sebanyak 3 kelas paralel dengan jumlah siswa seluruhnya 116 orang siswa. Teknik pengambilan sampel dilakukan secara cluster random sampling sebanyak dua kelas, dimana kelas X-2 sebagai kelas eksperimen dengan jumlah siswa 35 orang diterapkan model pembelajaran inquiry training dan kelas X-4 sebagai kelas kontrol dengan jumlah siswa 35 orang diterapkan pembelajaran konvensional.

Variabel penelitian ini terdiri dari 2 (dua) jenis, yaitu variabel bebas dan variabel terikat. Pada penelitian ini yang menjadi variabel bebas adalah model pembelajaran inquiry training, sedangkan variabel moderator pada penelitian ini adalah motivasi dan variabel terikat adalah hasil belajar.

Jenis penelitian ini termasuk penelitian quasi eksperimen, yang bertujuan untuk mengetahui ada tidaknya akibat dari suatu yang dikenakan pada subjek didik yaitu siswa. Penelitian ini melibatkan dua kelas sampel yang diberi perlakuan yang berbeda. Pada kelas eksperimen diberi perlakuan yaitu model pembelajaran inquiry training. Sedangkan pada kelas kontrol diberi perlakuan yang biasa dilakukan sekolah dengan pembelajaran konvensional. Adapun desain penelitian yang digunakan adalah desain anava $2 \times 2$.

Untuk memperoleh data yang diperlukan pada penelitian ini, peneliti menggunakan dua instrumen pengumpulan data. Instrumen penelitian tes dalam penelitian ini adalah tes motivasi dalam bentuk angket yang telah diuji validitas, reliabilitas, taraf kesukaran dan daya pembedanya. Instrumen kedua adalah tes hasil belajar dalam bentuk soal butir soal (pilihan ganda) yang sesuai dengan taksonomi Bloom revisi. Tes ini juga telah diuji validitas, reliabilitas, taraf kesukaran dan daya pembedanya.

\section{HASIL PENELITIAN}

Deskripsi data yang disajikan dalam penelitian ini terdiri dari skor hasil belajar (HB) kelas kontrol dan kelas eksperimen. Pada tahapan penelitian ini kedua kelas sampel yaitu kelas eksperimen diajarkan dengan model Inquiry Training (IT) dan kelas kontrol akan diajarkan dengan Pembelajaran Konvensional (PK). Data hasil pretes dapat dilihat pada Tabel 1 . Selanjutnya dilakukan uji normalitas untuk mengetahui kedua kelas berdistribusi secara normal dengan menggunakan SPSS 16.0. Uji normalitas belajar ditunjukkan pada Tabel 2 .

Kelas kontrol diperoleh nilai $\mathrm{L}_{\text {hitung }}$ sebesar 0,136 dan signifikansi sebesar 0,099 ( $\left.\mathrm{L}_{\text {tabel }}=0,154, \alpha=0,05\right)$. 
D.M. Pardede dan S.R. Manurung: Pengaruh Model Pembelajaran Inquiry Training dan Motivasi terhadap Hasil Belajar Fisika Siswa

Hasil menunjukkan bahwa $\mathrm{L}_{\text {hitung }}<\mathrm{L}_{\text {tabel }}$ dan signifikansi lebih besar dari 0,05, maka data pada kelas kontrol adalah berdistribusi normal. Uji kesamaan varians dan rata-rata nilai pretes dilakukan dengan Test of Homogenety of Variance menggunakan SPSS 16.0 dengan hasil pengujian pada Tabel 3.

\section{Tabel 1. Hasil Pretes Kelas Ekperimen dan Kelas Kontrol}

\begin{tabular}{|l|c|c|}
\hline Kelas & Jumlah & Rata-rata \\
\hline Eksperimen & 35 & 3,85 \\
\hline Kontrol & 35 & 3,97 \\
\hline
\end{tabular}

Tabel 2. Uji Normalitas Pretes Hasil Belajar Siswa

\begin{tabular}{|c|l|c|c|c|c|}
\hline No & Uji Normalitas & Lhitung $_{\text { }}$ & L $_{\text {tabel }}$ & Sig & Ket. \\
\hline 1 & Kontrol & 0.136 & 0.154 & 0.099 & Normal \\
\hline 2 & Eksperimen & 0.138 & 0.152 & 0.092 & Normal \\
\hline
\end{tabular}

Tabel 3. Uji Homogenitas Pretes

\begin{tabular}{|c|c|c|c|c|}
\hline Uji Homogenitas & F $_{\text {hitung }}$ & F $_{\text {tabel }}$ & Sig & Ket. \\
\hline Berdasarkan rerata & 0.009 & 3.99 & 0.924 & Homogen \\
\hline
\end{tabular}

Hasil pengujian memperlihatkan nilai $F_{\text {hitung }}$ untuk pretes hasil belajar 0,009 dengan signifikansi 0,924 $\left(\mathrm{F}_{\text {tabel }}=\right.$ 3,99, $\alpha=0,05)$. Berdasarkan hasil tersebut $F_{\text {hitung }}<F_{\text {tabel }}$ dan signifikan hitung lebih besar dibandingkan $\alpha=0,05$ sehingga dapat disimpulkan data pretes hasil belajar kelas kontrol dan kelas eksperimen memiliki varians yang sama atau homogen. Uji normalitas dan uji homogenitas dari kedua kelas sampel dibutuhkan sebagai uji prasyarat untuk melakukan uji kesamaan kemampuan awal (uji t dua pihak). Karena data kedua kelas normal dan homogen maka dapat dilakukan uji kesamaan kemampuan awal dari kedua kelas sampel.Uji kesamaan varians dan rata-rata nilai pretes dilakukan dengan uji $t$ sampel bebas menggunakan SPSS 16.0 dengan hasil pengujian pada Tabel 4.

Tabel 4. Uji Kesamaan Kemampuan Awal

\begin{tabular}{|c|c|c|c|c|}
\hline Pengujian & $\mathbf{t}_{\text {hitung }}$ & $\mathbf{t}_{\text {tabel }}$ & Sig & \multicolumn{1}{|c|}{ Keterangan } \\
\hline Uji t & 0.314 & 1.67 & 0.754 & $\begin{array}{l}\text { Sama (tidak } \\
\text { signifikan berbeda) }\end{array}$ \\
\hline
\end{tabular}

Berdasarkan pengujian kesamaan kemampuan awal dengan hasil thitung 0,314 dan signifikansi sebesar $0,754\left(\mathrm{t}_{\text {tabel }}=1,67, \alpha=0,05\right)$. Hasil ini menunjukkan bahwa $-\mathrm{t}_{\text {tabel }} \leq \mathrm{t}_{\text {hitung }} \leq \mathrm{t}_{\text {tabel }}$ dan nilai signifikansi lebih besar dibandingkan 0,05. Berdasarkan hasil tersebut disimpulkan bahwa tidak ada perbedaan kemampuan awal hasil belajar di kelas eksperimen dengan kelas kontrol atau dengan kata lain kedua kelas memiliki kemampuan awal yang sama.
Jurnal Pendidikan Fisika p-ISSN 2252-732X e-ISSN 2301-7651
Selain hasil penelitian berupa nilai hasil belajar, deskripsi hasil juga memuat data motivasi. Deskripsi data yang disajikan dalam penelitian ini terdiri dari skor motivasi dengan menggunakan model pembelajaran inquiry training dan pembelajaran konvensional. Pada tahapan penelitian kedua kelas sampel yaitu kelas inquiry training dan kelas pembelajaran konvensional diberikan angket motivasi yang bertujuan untuk melihat motivasi siswa pada kedua kelas tersebut. Kelas dengan pembelajaran konvensional memiliki rerata motivasi dengan nilai 76,17 dan kelas Inquiry Training memiliki rerata motivasi dengan nilai 75,77 . Untuk pembagian kelompok tinggi dan rendah maka data di atas dibagi dalam 2 (dua) kelas. Data motivasi kedua kelas ini kemudian digabung menjadi satu dan dikelompokan menjadi 2 (dua) kelompok yaitu kelompok tinggi dan rendah berdasarkan median dengan interval yang dapat dilihat pada Tabel 5.

Tabel 5. Pembagian Kelompok Motivasi Tinggi dan Rendah

\begin{tabular}{|c|c|c|c|}
\hline \multirow{2}{*}{ Kelompok } & \multirow{2}{*}{ Interval Skor } & \multicolumn{2}{|c|}{ Jumlah } \\
\cline { 3 - 4 } & & PK & IT \\
\hline Tinggi & $76-86$ & 17 & 19 \\
\hline Rendah & $68-75$ & 18 & 16 \\
\hline
\end{tabular}

Setelah diberikan uji pretes kepada siswa maka selanjutnya diberikan perlakuan sesuai dengan model yang digunakan pada masing-masing kelas dimana pada kelas eksperimen diberikan model pembelajaran inquiry training dan pada kelas kontrol diberikan pembelajaran konvensional. Setelah perlakuan maka diberikan postes kepada siswa. Di mana hasil postes dapat dilihat pada Tabel 6.

\section{Tabel 6. Hasil Postes pada Kelas Eksperimen dan Kelas Kontrol}

\begin{tabular}{|l|c|c|}
\hline \multicolumn{1}{|c|}{ Kelas } & Jumlah & Rata-rata \\
\hline Eksperimen & 35 & 11,28 \\
\hline Kontrol & 35 & 9,88 \\
\hline
\end{tabular}

Berdasarkan hasil penelitian nilai postes hasil belajar pada kelas kontrol dengan model pembelajaran konvensional didapat rerata 9,88 dan kelas eksperimen dengan model pembelajaran inquiry training didapat rerata 11,28. Data postes hasil belajar siswa dikelompokan berdasarkan kelompok motivasinya yaitu kelompok tinggi dan rendah. Hasil belajar kelompok motivasi rendah dan tinggi dilihat pada Tabel 7.

Hasil belajar yang diajarkan dengan model pembelajaran konvensional (PK) dan motivasi rendah (MR) diperoleh rerata 9,83 sedangkan pada motivasi tinggi (MT) dengan model pembelajaran konvensional (PK) diperoleh rerata 9,94 . 
D.M. Pardede dan S.R. Manurung: Pengaruh Model Pembelajaran Inquiry Training dan Motivasi terhadap Hasil Belajar Fisika Siswa

Tabel 7. Data Disain Faktorial Rata-rata HB antar Model Pembelajaran dan Motivasi

\begin{tabular}{|l|l|l|l|}
\hline \multirow{2}{*}{$\begin{array}{c}\text { Kelompok } \\
\text { Motivasi }\end{array}$} & \multicolumn{2}{|c|}{ Rerata HB } & \multirow{2}{*}{ PK } \\
\cline { 2 - 3 } IT & \\
\hline Tinggi & 9,94 & 12,16 & 11,11 \\
\hline Rendah & 9,83 & 10,25 & 10,03 \\
\hline Rerata & 9,88 & 11,28 & - \\
\hline
\end{tabular}

Hasil belajar yang diajarkan dengan model pembelajaran inquiry training (IT) pada kelompok motivasi rendah diperoleh rerata 10,25 dan pada kelompok motivasi tinggi (MT) dengan model pembelajaran inquiry training (IT) diperoleh rerata 12,16. Setelah pengelompokan siswa dilakukan maka, dapat dilakukan uji hipotesis dengan menggunakan analisis varians (Anava) dua jalur. Tabel 8. Berikut ini menyajikan hasil analisis Anava dengan bantuan SPSS 16.0.

Tabel 8. Output Perhitungan ANAVA Dua Jalur

\begin{tabular}{|c|c|c|c|c|c|}
\hline Source & $\begin{array}{c}\text { Type III } \\
\text { Sum of } \\
\text { Squares }\end{array}$ & Df & $\begin{array}{c}\text { Mean } \\
\text { Square }\end{array}$ & F & Sig. \\
\hline Model & 30.215 & 1 & 30.215 & 10.023 & 0.002 \\
\hline Motivasi & 17.704 & 1 & 17.704 & 5.873 & 0.018 \\
\hline $\begin{array}{c}\text { model } * \\
\text { motivasi }\end{array}$ & 14.118 & 1 & 14.118 & 4.683 & 0.034 \\
\hline
\end{tabular}

Berdasarkan Tabel 9 hasil perhitungan Anava dua jalur terdapat perbedaan hasil belajar antara siswa yang diajarkan menggunakan model pembelajaran inquiry training dengan siswa yang diajarkan menggunakan model pembelajaran konvensional, karena $\alpha=0,05>$ sig 0.002 dan $F_{\text {hitung }}>F_{\text {tabel }}(10,023>4,01)$. Bagian motivasi diperoleh nilai signifikansi sebesar 0,018 , artinya terdapat perbedaan hasil belajar siswa antara siswa yang memiliki motivasi rendah dengan siswa yang memiliki motivasi tinggi, karena $\alpha=0,05>\operatorname{sig} 0,018$ dan $F_{\text {hitung }}>F_{\text {tabel }}(5,873$ $>3,16)$.

Bagian interaksi diperoleh nilai signifikansi sebesar 0,034, artinya ada interaksi antara pembelajaran konvensional dan inquiry training dengan motivasi dalam mempengaruhi hasil belajar, karena $\alpha=0,05>$ sig 0,034 dan $F_{\text {hitung }}>F_{\text {tabel }}(4,683>3,16)$. Hasil interaksi antara model pembelajaran dan motivasi dapat dilihat pada Gambar 1. Berdasarkan Gambar 1 terlihat bahwa siswa yang diajarkan dengan pembelajaran konvensional memiliki rerata hasil kelompok motivasi tinggi sebesar 9,94 dan motivasi rendah sebesar 9,83. Sedangkan siswa yang diajarkan dengan model inquiry training memiliki rerata hasil kelompok motivasi tinggi sebesar 12,16 dan motivasi rendah sebesar 10,25. Grafik antara motivasi tinggi dan rendah pada model pembelajaran inquiry training dan pembelajaran konvensional berpotongan pada satu titik. Perpotongan ini menunjukan adanya interaksi
Jurnal Pendidikan Fisika p-ISSN 2252-732X e-ISSN 2301-7651 antara model pembelajaran dan motivasi terhadap hasil belajar siswa.

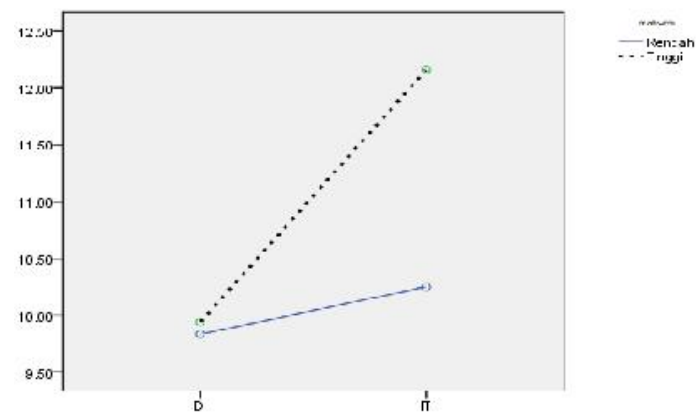

Gambar 1. Grafik Interaksi Uji Hipotesis

\section{PEMBAHASAN}

Hasil uji statistik pada penelitian ini dengan menggunakan anava dua jalur untuk mengetahui apakah hasil belajar siswa dengan menggunakan model pembelajaran inquiry training lebih baik dari model pembelajaran konvensional. Untuk mengetahui apakah hasil belajar siswa yang memiliki motivasi tinggi lebih baik dari hasil belajar siswa yang memiliki motivasi rendah, dan untuk mengetahui interaksi model pembelajaran inquiry training dan motivasi terhadap hasil belajar siswa. Hasil yang diperoleh dalam penelitian ini menunjukkan terdapat perbedaan hasil belajar pada kelas ekspeimen yang menggunakan model pembelajaran inquiry training dan kelas kontrol dengan menggunakan model pembelajaran konvensional. Di mana hasil belajar dengan menggunakan model pembelajaran inquiry training lebih baik dari pada dengan menggunakan model pembelajaran konvensional. Dimana hasil belajar dengan menggunakan model pembelajaran inquiry training lebih baik dari pada dengan menggunakan model pembelajaran konvensional. Hal ini menunjukkan bahwa model pembelajaran inquiry training lebih efektif dalam meningkatkan hasil belajar temuan ini diperkuat dari ratarata hasil belajar kelas eksperimen lebih tinggi dari pada nilai rata-rata kelas kontrol di mana rata-rata hasil belajar kelas eksperimen sebesar 11,28 sementara nilai rata-rata kelas kontrol sebesar 9,88. Dari nilai tersebut dapat dilihat bahwa hasil belajar dengan menggunakan model pembelajaran inquiry training lebih baik dari pada dengan menggunakan model pembelajaran konvensional. Hal ini karena model pembelajaran inquiry training melibatkan siswa secara aktif menemukan ilmu pengetahuan sendiri melalui proses penyelidikan.

Kesimpulan di atas sama dengan hasil penelitian sebelumnya. Mudjiono (2009) menyimpulkan terdapat pengaruh model pembelajaran inquiry training berbatuan portopolio dengan menggunakan media komputer terhadap hasil belajar. Vaishnav (2013) menyimpulkan bahwa model inquiry training efektif meningkatkan prestasi belajar siswa. Pandey (2011) menyimpulkan bahwa model inquiry training lebih efektif dalam meningkatkan prestasi 
D.M. Pardede dan S.R. Manurung: Pengaruh Model Pembelajaran Inquiry Training dan Motivasi terhadap Hasil Belajar Fisika Siswa
Jurnal Pendidikan Fisika

p-ISSN 2252-732X

e-ISSN 2301-7651 akademik siswa dibanding metode konvensional. Mustachido (2013) yang menyimpulkan model inkuiri dapat meningkatkan prestasi belajar siswa SMA

Hasil penelitian juga menunjukkan disimpulkan siswa yang memiliki motivasi belajar yang tinggi akan memperoleh hasil belajar yang lebih baik dibandingkan siswa yang memiliki motivasi belajar rendah. Zubaidah (2008) menyimpulkan siswa yang memiliki motivasi yang tinggi memperoleh hasil belajar IPA yang lebih baik dari pada siswa yang memiliki motivasi rendah. Terdapat interaksi antara model pembelajaran inquiry training dan motivasi terhadap hasil belajar siswa. Hal ini sesuai dengan hasil penelitian lain Pramunkantoro (2014) menyimpulkan ada interaksi antara model pembelajaran dan motivasi terhadap prestasi belajar siswa.

\section{KESIMPULAN DAN SARAN}

Ada perbedaan hasil belajar siswa yang dibelajarkan dengan model pembelajaran inquiry training dan model pembelajaran konvensional. Hasil belajar siswa yang diajarkan dengan model pembelajaran inquiry training lebih baik dari hasil belajar siswa yang diajarkan dengan model pembelajaran konvensional. Begitu juga dengan motivasi Ada perbedaan hasil belajar siswa yang mempunyai motivasi tinggi dan motivasi rendah. Hasil belajar siswa yang mempunyai motivasi tinggi lebih baik dari hasil belajar siswa yang mempunyai motivasi rendah. Hal yang sama juga dalam interaksi Ada interaksi antara model pembelajaran dan motivasi terhadap hasil belajar siswa. Hasil belajar siswa yang diajarkan dengan model inquiry training dipengaruhi juga oleh motivasi, sedangkan hasil belajar siswa yang diajarkan dengan pembelajaran konvensional signifikan dipengaruhi motivasi.

Berdasarkan hasil dan kesimpulan penelitian ini, maka peneliti memiliki beberapa saran untuk menerapkan model pembelajaran inquiry training yaitu (1) Dalam penerapan model pembelajaran inquiry training guru harus memperhatikan motivasi siswa, karena model ini tepat untuk siswa yang motivasi tinggi. (2) Untuk siswa yang memiliki motivasi rendah disarankan untuk tidak diajarkan dengan model pembelajaran inquiry training karena siswa akan kesulitan dalam melakukan proses inquiry (penemuan) selama pembelajaran, siswa sulit menganalisis data dan fenomena alam yang mereka temukan selama pembelajaran. (3) Disarankan kepada peneliti lanjutan, kiranya dapat melanjutnya penelitian ini dengan menerapkan model pembelajaran inquiry training dengan bantuan metode ataupun media pembelajaran kreatif dalam proses pembelajaran untuk meningkatkan hasil belajar siswa.

\section{REFERENSI}

Arends. R. (2007). Learning to Teach (seven edition). New York: Mc Grawn Hill Companies. Inc
Driana. (2013). Gawat Darurat Pendidikan Nasional. Diakses: November 2013.

Joyce, B., Weil, M., \& Calhoun, E. (2009). models of teaching (edisi kedelapan). Model-Model Pengajaran (Terjemahan Achmad Fawai \& Ateila Mirza). Yogyakarta: Pustaka Pelajar

Mustachfidoh. (2013). Pengaruh Model Pembelajaran Inkuiri Terhadap Prestasi Belajar Biologi Ditinjau Dari Inteligensi Siswa SMA Negeri 1 Srono. e-Journal Program Pascasarjana Universitas Pendidikan Ganesha Program Studi Pendidikan Sains 3(5): 20-23. Diakses: Agustus 2013

Pandey. (2011). Effectiveness of Inquiry Training Model Over Conventional Teaching Method on Academic Achivement of Student in India. Journal of Innovative Research in Education 1(1): 21-27. Maret, 2011. Dhanbad-India

Pramukantoro, J \& Wiratam, D. (2014). Perbedaan Model Pembelajaran Guided Inquiry dan MPL terhadap Prestasi Belajar Siswa yang Memiliki Motivasi Prestasi Berbeda Mada mata Pelajaran Teknik Listrik. Jurnal Pendidikan Teknik Elektro 3(1): 179-185. Diakses: November 2014

Sani, A. R. (2013). Inovasi Pembelajaran. Jakarta: Bumi Aksara

Siddiqui, M., H. (2013). Inquiry Training Model of Teaching. IJSR-International Journal of Scientific Research vol 2.Tersedia: globaljournals.com, diakses: 25 nopember 2013

Tella, A. (2007). The impact of motivation on student's Academic Achievement and learning Outcomes in School Students in Nigeria. Journal of innovation Research Education. Diakses: 28 Nopember 2014

Vaishnav, R.S. (2013). Effectivness of Inquiry Training Model for Teaching Science. Scholarly Reseach Journal for Interdisciplinary Studies. 1(5):32-40. April 2013. Nagpur-India

Zubaidah, S. (2008). Pembelajaran Kontekstual dengan metode inkuiri dan motivasi belajar IPA. Jurnal Pendidikan dan Pembelajaran. Vol 5(1): 19-25. 